\title{
Agronomic performance of Raphanus sativus L. cultivars grown under different spacings
}

\author{
Rendimiento agronómico de los cultivares de Raphanus sativus L. \\ con diferentes espaciamientos
}

Jorgeana Francis Alvim¹; Oswaldo Palma Lopes Sobrinho²; Erika de Kássia Pereira Cantanhede ${ }^{3}$; Álvaro Itaúna Schalcher Pereira ${ }^{4}$; Valdelânia Gomes da Silva ${ }^{5}$; Leonardo Nazário Silva dos Santos ${ }^{6}$

\begin{abstract}
$\frac{\text { ARTICLE DATA }}{1 \text { Researcher, Agronomist. Federal Institute of Edu- }}$ cation, Science, and Technology of Maranhão, Codó, Brazil, jorgeanaalvim@gmail.com

Researcher, MSc. Federal Institute Goiano, Rio Verde, Brazil, oswaldo-palma@hotmail.com

Researcher, M.Sc. Federal Institute of Education, Science, and Technology of Maranhão, Codó, Brazil, erikamorga@hotmail.com

4 Professor, Ph.D. Federal Institute of Education, Science, and Technology of Maranhão, Codó, Brazil, alvaro.pereira@ifma.edu.br

5 Professor, Ph.D. Federal Institute of Education, Science, and Technology of Maranhão, Codó, Brazil, vadelbio@gmail.com

6 Professor, Ph.D. Federal Institute Goiano, Rio Verde, Brazil, leonardo.santos@ifgoiano.edu.br
\end{abstract}

Cite: Alvim, J. F.; Lopes Sobrinho, O. P.; Cantanhede, E. K. P.; Pereira, A. I. S.; Silva, V. G.; Santos, L. N. S. (2020). Agronomic performance Raphanus sativus L. cultivars under different spacing. Revista de Ciencias Agrícolas. 37(2): 19-26.

doi: https://doi.org/10.22267/rcia.203701.126

Received: July 242019.

Accepted: May 052020.

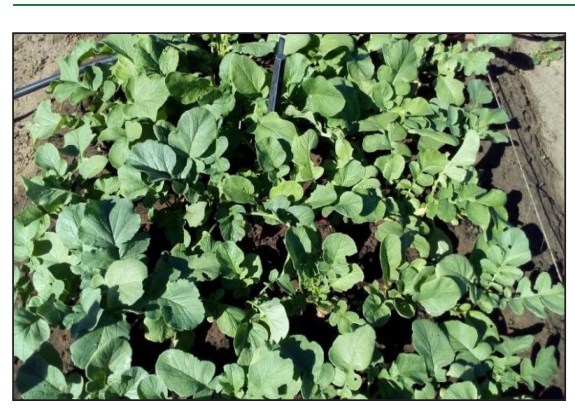

ABSTRACT

An ideal spacing between plants should be established for the optimization of radish (Raphanus sativus L.) crops since the plant spatial distribution of plants affects the crop yield. This study was conducted aiming to evaluate the agronomic performance of radish cultivars grown under different spacings. The experiment was conducted at the Experimental Field of the Federal Institute of Education, Science, and Technology of Maranhão, in Codó, MA, Brazil, from June to July 2017. The experiment was conducted in a randomized block design with five replications, using a $2 \times 2$ factorial arrangement. The factors consisted of 2 cultivars (Sparkler Ponta Branca and Saxa) and 2 spacings between plants ( 5 and $8 \mathrm{~cm}$ ), totaling 20 experimental plots. Data were collected in 6 plants from each experimental plot. The agronomic parameters: total fresh weight (TFW), root fresh weight (RFW), root mean diameter (RMD), root means length (RML), and rootyield (RY) of the radish plants were evaluated. The factors (cultivars and spacing between plants) had no significant effect on TFW, RFW, RML, and RMD. The spacing between plants has a significant effect on the yield of radish crops of the cultivar Saxa, and higher yields are found when using the spacing of $5 \mathrm{~cm}$.

Keywords: Plant spatial arrangement; production components; horticulture; yield.

\section{RESUMEN}

Debe establecerse un espacio ideal entre las plantas para optimizar los cultivos de rábano (Raphanus sativus L.), ya que la distribución espacial de las plantas afecta al rendimiento de los cultivos. Este estudio se realizó con el objetivo de evaluar el rendimiento agronómico de los cultivos de rábano cultivados con diferentes espaciamientos. El experimento se llevó a cabo en el Campo Experimental del Instituto Federal de Educación, Ciencia y Tecnología de Maranhão, en Codó, MA (Brasil), de junio a julio de 2017. 
Alvim et al.- Agronomic performance of Raphanus sativus L.

El experimento se llevó a cabo en un diseño de bloques aleatorios con cinco réplicas, utilizando un arreglo factorial de $2 \times 2$. Los factores consistían en 2 cultivares (Sparkler Ponta Branca y Saxa) y 2 espaciamientos entre plantas (5 y $8 \mathrm{~cm}$ ), totalizando 20 parcelas experimentales. Se recogieron datos en 6 plantas de cada parcela experimental. Se evaluaron los parámetros agronómicos: peso fresco total (PFT), peso fresco de las raíces (PFR), diámetro medio de las raíces (DMR), longitud media de las raíces (LMR) y rendimiento de las raíces (RR) de las plantas de rábano. Los factores (cultivares y espaciamiento entre plantas) no tuvieron un efecto significativo en el PFR, PFR, LMR y DMR. El espaciamiento entre plantas tiene un efecto significativo en el rendimiento de los cultivos de rábano del cultivar Saxa, y se encuentran rendimientos más altos cuando se utiliza el espaciamiento de $5 \mathrm{~cm}$.

Palabras clave: disposición espacial de las plantas; componentes de la producción; horticultura; productividad.

\section{INTRODUCTION}

Radish (Raphanus sativus L.) is a vegetable native from the Mediterranean region (Rodrigues et al., 2013), belongs to the Brassicaceae family, the same family of cauliflower, oilseed radish, rocket, cabbage, and others. The plants usually have small sizes, tuberous roots, and green compound leaves with leaflets and lobes (Guimarães and Feitosa, 2014).

The consumption of vegetables has increased in the last years due to the search for healthier foods with nutraceutical properties (Cunha et al., 2017), considering that the population is aware of the benefits and properties of these foods. It increases the responsibility and challenges for rural producers who need to increase crop yields and search for tools to control and mitigate the occurrence of pests and diseases and, also, search for compatible sustainable production systems that ensure the availability of foods to consumers and, consequently, the growth of the food production sector (Montezano and Peil, 2006).

The world radish production is estimated at 7 million Mg year-1. Japan is one of the largest radish producers (Linhares et al., 2010; Ito and Horie, 2008). In Brazil, radish is grown mainly in the South and Southwest regions, showing yields from 11 to $30 \mathrm{Mg} \mathrm{ha}^{-1}$ and a production cost of BRL (R\$) 10,000 to 14,000 per hectare
(Melo, 2017). Despite present in several Brazilian recipes, radish crops have not been emphasized in Brazil regarding the crop area and production volume (Cecílio Filho and May, 2002).

Radish presents the lowest expressiveness in Brazil among marketed vegetables (Puliti et al., 2009). Therefore, it can be grown in small size properties along with green belts of large cities, enabling a faster financial return and higher income in periods between seasons of crops of longer cycles (Cardoso and Hiraki, 2001; Oliveira et al., 2010). Thus, radish is a good alternative crop, mainly for small farmers, since it can be grown throughout the year and between other crop seasons (Bonela et al., 2017).

The crop spacing between rows and between plants and the number of plants per pit are factors that define the plant population to be grown. Climate, soil, and plant chemical and physical characteristics, crop management, and cultural practices should be considered to determine these factors (Severino et al., 2006). Studies on radish crops for the Cocais administrative region of the state of Maranhão, Brazil, are scarce. In this context, this study was conducted aiming to evaluate the agronomic performance of radish ( $R$. sativus $L$.) cultivars grown under different spacings. 


\section{MATERIAL AND METHODS}

The experiment was conducted with radish crops at the Experimental Field of the Federal Institute of Education, Science, and Technology of Maranhão, in Codó, in the mesoregion East of the state of Maranhão, Brazil (426'51"S, $43^{\circ} 52^{\prime} 57^{\prime \prime} \mathrm{W}$, and altitude of $48 \mathrm{~m}$ ) (Castro Júnior et al., 2015).

According to Köppen and Geiger (1928), the climate of the region is Aw; the mean air temperature is $27.4^{\circ} \mathrm{C}$; the mean annual rainfall depth is $1.526 \mathrm{~mm}$. August is the driest month, with a rainfall depth of $12 \mathrm{~mm}$, and March presents the highest mean rainfall depth $(307 \mathrm{~mm})$. September is the hotter month with a mean temperature of $28.8^{\circ} \mathrm{C}$. The soil of the area was classified as Typic Quartzipsamment (Santos et al., 2018).

Soil samples from the $0.0-0.20 \mathrm{~m}$ layer were collected and sent to the Laboratory of Soil Analysis of the Federal University of Piauí (UFPI) for soil chemical characterization; the results are shown in Table 1.

Soil chemical analysis indicated that liming was not needed. A soil organic fertilizer (cured caprine manure) was used at 20L per plot of $1 \mathrm{~m}^{2}$. A chemical fertilizer (N-P-K) was applied according to the soil analyses and recommendations of the Manual of Fertilization and Liming (Aquino et al., 1993).
Urea $\left(\mathrm{CH}_{4} \mathrm{~N}_{2} \mathrm{O}\right)$, simple superphosphate $\left(\mathrm{P}_{2} \mathrm{O}_{5}\right)$, and potassium chloride $(\mathrm{KCl})$ were applied to the radish beds. The soil chemical fertilizers were applied in two phases: soil fertilization at planting, using $\mathrm{P}$ and $\mathrm{K}$; and a topdressing at 15 days after planting, using $\mathrm{N}$ and $\mathrm{K}$.

The area was chosen and delimited, and a brush cutting and weeding were carried out through a harrowing of the area. The beds were then manually raised using a hoe. Cured caprine manure was applied to the beds and incorporated into the soil, and the area was leveled using a rake. The plots were then established by dividing beds of $2 \times 1 \mathrm{~m}$ into two plots.

The following cultural practices were carried out during the crop cycle: adding soil to the plants' base, removal of weeds, manual hoeing, and plant health protection. The plants were harvested at 30 days after sowing, on July 18, 2017. A localized irrigation method was used, with a micro-sprinkler system.

The evaluated variables were: total fresh weight (g plant ${ }^{-1}$ ), using a digital balance; root fresh weight ( $\mathrm{g} \mathrm{plant}^{-1}$ ), for which leaves were cut at their base to remove them from the roots, and the roots were weighed in a digital balance; root-mean diameter (mm), using a caliper to measure the transversal diameter; root mean length (mm), measuring the root length of each plant with a caliper, and dividing the result by the number of plants in the evaluation area; root yield $\left(\mathrm{kg} \mathrm{ha}^{-1}\right)$, which is the weight of radish roots produced divided by the planted area.

Table 1. Chemical characteristics of the soil of the experimental area.

\begin{tabular}{cccccccccc}
\hline Layer & $\mathbf{p H}$ & $\mathbf{P}$ & $\mathbf{K}$ & $\mathbf{N a}$ & $\mathbf{C a}$ & $\mathbf{M g}$ & $\mathbf{A l}$ & $\mathbf{H + A l}$ \\
\hline $\mathbf{m}$ & $\mathbf{H}_{\mathbf{2}} \mathbf{0}$ & \multicolumn{2}{c}{$\mathbf{m g ~ d m}^{\mathbf{3}}$} & \multicolumn{5}{c}{$\mathbf{c m o l c ~} \mathbf{~ d m}^{\mathbf{3}}$} \\
\hline $0.0-0.20$ & 6.6 & 0.2 & 21.5 & 7.9 & 4.2 & 4.1 & 0 & 3.07 \\
\hline
\end{tabular}


A randomized block experimental design was used, in a $2 \times 2$ factorial arrangement, with five replications. The treatments consisted of two cultivars (Sparkler Ponta Branca and Saxa) grown under different spacings between plants (5 and $8 \mathrm{~cm}$ ), totaling 20 experimental plots, with 6 evaluated plants per plot.

Thus, the treatments were: Sparkler Ponta Branca with a spacing of $5 \mathrm{~cm}$ (T1); Sparkler Ponta Branca with a spacing of 8cm (T2); Saxa with a spacing of $5 \mathrm{~cm}$ (T3); and Saxa with a spacing of $8 \mathrm{~cm}(\mathrm{~T} 4)$.

The data found were subjected to analysis of variance (ANOVA) by the $\mathrm{F}$ test. The means were evaluated through comparison by the Tukey's test at 5\% probability, level using the Assistat ${ }^{\circledR}$ 7.7 beta program (Silva and Azevedo, 2016).

\section{RESULTS AND DISCUSSION}

According to the analysis of variance (Table 2), the factor cultivar (Sparkler Ponta and Saxa) had no significant effect $(P \geq 0.05)$ on the total fresh weight (TFW), root fresh weight of (RFW), root mean diameter (RMD), root mean length (RML) and root yield (RY) of radish plants; and the factor spacing between plants ( 5 and $8 \mathrm{~cm}$ ) had no significant effect $(P \geq 0.05)$ on the variables TFW, RFW, RML, and RMD. However, the spacing between plants ( 5 and $8 \mathrm{~cm}$ ) had a significant effect $(P<0.01)$ on RY, showing lower RY when using the spacing between plants of $8 \mathrm{~cm}$.

These results are explained by the effect of climate conditions since oscillations in soil moisture and temperature throughout the crop cycle affect the yield and quality of radish roots (Costa et al., 2006).

Table 2. Analysis of variance for the total fresh weight (TFW), root fresh weight of (RFW), root mean diameter (RMD), root mean length (RML), and root yield (RY) of radish plants of different cultivars (Sparkler Ponta and Saxa) grown under different spacings between plants $(5$ and $8 \mathrm{~cm})$.

\begin{tabular}{llllll}
\hline Treatments & TFW & RFW & RML & RMD & RY \\
\hline Cultivar & $1.7373^{\text {ns }}$ & $0.0087^{\text {ns }}$ & $0.5594^{\text {ns }}$ & $0.4916^{\text {ns }}$ & $0.0807^{\text {ns }}$ \\
Spacing & $0.3436^{\text {ns }}$ & $0.0780^{\text {ns }}$ & $0.0601^{\text {ns }}$ & $0.3673^{\text {ns }}$ & $12.3411^{* *}$ \\
\hline
\end{tabular}

** $=$ significant at $1 \%$ probability level $(p<0.01)$, and ns $=$ not significant $(p>0.05)$ by the $\mathrm{F}$ test.

The cultivar (Sparkler Ponta and Saxa) and spacing between plants (5 and $8 \mathrm{~cm}$ ) had no significant effect $(P \geq 0.05)$ on TFW (Table 3$)$. Caron et al. (2004) found similar results that corroborate those found in the present work; they explain that the shoot fresh weight of radish plants determines the leaf area and is directly correlated to the production and distribution of photoassimilates and allocation of biomass, mainly in leafy vegetables.
Table 3. Total fresh weight (TFW) of radish plants of different cultivars (Sparkler Ponta and Saxa) grown under different spacings between plants ( 5 and $8 \mathrm{~cm}$ ).

\begin{tabular}{lcc}
\hline Cultivar & $\begin{array}{c}\text { Spacing } \\
(\mathbf{2 0} \times \mathbf{5} \mathbf{~ c m})\end{array}$ & $\begin{array}{c}\text { Spacing } \\
(\mathbf{2 0} \times \mathbf{8} \mathbf{~ c m})\end{array}$ \\
\hline Sparkler Ponta & $57.50 \mathrm{Aa}$ & $61.05 \mathrm{Aa}$ \\
Saxa & $55.40 \mathrm{Aa}$ & $42.80 \mathrm{Aa}$ \\
\hline
\end{tabular}

Means followed by the same lowercase letter in the columns, or uppercase letter in the rows, are not different by Tukey's test at $5 \%$ probability. 
The cultivar (Sparkler Ponta and Saxa) and spacing between plants ( 5 and $8 \mathrm{~cm}$ ) had no significant effect $(P \geq 0.05)$ on RFW (Table 4$)$. These are similar results to those found by ElDesuki et al. (2005), Rezende et al. (2006) and Bonela et al. (2017), who found no significant differences for RFW in radish plants of the cultivar Crimson Giant, Saxa, Sparkler Ponta Branca, Red Jewel F1, and No. 25.

Table 4. Root fresh weight (RFW) of radish plants of different cultivars (Sparkler Ponta and Saxa) grown under different spacings between plants ( 5 and $8 \mathrm{~cm}$ ).

\begin{tabular}{|c|c|c|}
\hline Cultivar & $\begin{array}{c}\text { Spacing } \\
(20 \times 5 \mathrm{~cm})\end{array}$ & $\begin{array}{c}\text { Spacing } \\
(20 \times 8 \mathrm{~cm})\end{array}$ \\
\hline Sparkler Ponta & $21.55 \mathrm{Aa}$ & $23.20 \mathrm{Aa}$ \\
\hline Saxa & $24.60 \mathrm{Aa}$ & $20.85 \mathrm{Aa}$ \\
\hline
\end{tabular}

Means followed by the same lowercase letter in the columns, or uppercase letter in the rows, are not different by Tukey's test at $5 \%$ probability.

The cultivar (Sparkler Ponta and Saxa) and spacing between plants ( 5 and $8 \mathrm{~cm}$ ) had no significant effect $(p \geq 0.05)$ on RMD (Table $5)$. Despite the lack of significance between the treatments, the presence of radish roots with problems, such as sponge-like texture, was not found. These problems result in radishes with a spongy texture, insipid taste, and cracks, thus compromising their quality (Filgueira, 2003).
Table 5. Root mean diameter (RMD) (mm) of radish plants of different cultivars (Sparkler Ponta and Saxa) grown under different spacings between plants ( 5 and $8 \mathrm{~cm}$ ).

\begin{tabular}{|c|c|c|}
\hline Cultivar & $\begin{array}{c}\text { Spacing } \\
(20 \times 5 \mathrm{~cm})\end{array}$ & $\begin{array}{c}\text { Spacing } \\
(20 \times 8 \mathrm{~cm})\end{array}$ \\
\hline Sparkler Ponta & $31.35 \mathrm{Aa}$ & $31.40 \mathrm{Aa}$ \\
\hline Saxa & $31.20 \mathrm{Aa}$ & $28.60 \mathrm{Aa}$ \\
\hline
\end{tabular}

Means followed by the same lowercase letter in the columns, or uppercase letter in the rows, are not different by Tukey's test at $5 \%$ probability.

Caetano et al. (2015) evaluated radish crops and found RMD of 19.47 and $18.20 \mathrm{~mm}$, which were similar results to those found in the present study. However, Salgado et al. (2006) and Vitti et al. (2007) found RMD of $3.5 \mathrm{~cm}$ for radish plants grown under organic soil fertilization.

The cultivar (Sparkler Ponta and Saxa) and spacing between plants ( 5 and $8 \mathrm{~cm}$ ) had no significant effect $(p \geq 0.05)$ on RML (Table 6). Cortez et al. (2010) reported that tall plants are not a desirable characteristic to increase radish yields.

Table 6. Root mean length ( $\mathrm{mm}$ ) of radish plants of different cultivars (Sparkler Ponta and Saxa) grown under different spacings between plants ( 5 and $8 \mathrm{~cm}$ ).

\begin{tabular}{|c|c|c|}
\hline Cultivar & $\begin{array}{c}\text { Spacing } \\
(20 \times 5 \mathrm{~cm})\end{array}$ & $\begin{array}{c}\text { Spacing } \\
(20 \times 8 \mathrm{~cm})\end{array}$ \\
\hline Sparkler Ponta & $47.20 \mathrm{Aa}$ & $50.30 \mathrm{Aa}$ \\
\hline Saxa & $54.25 \mathrm{Aa}$ & $49.20 \mathrm{Aa}$ \\
\hline
\end{tabular}

Means followed by the same lowercase letter in the columns, or uppercase letter in the rows, are not different by Tukey's test at $5 \%$ probability. 
The cultivar (Sparkler Ponta and Saxa) had no significant effect $(p \geq 0.05)$ on RY. However, the spacing between plants had a significant effect $(p<0.01)$ on RY, showing lower RY when using the spacing between plants of $8 \mathrm{~cm}$ (Table 7). According to Cecílio Filho et al. (1998), mineral nutrition for plants has a high effect on the crop, affecting root qualitative aspects and, mainly, the crop yield.

Table 7. Root yield (RY) of radish plants of different cultivars (Sparkler Ponta and Saxa) grown under different spacings between plants (5 and $8 \mathrm{~cm}$ ).

\begin{tabular}{lcc}
\hline \multicolumn{1}{c}{ Cultivar } & $\begin{array}{c}\text { Spacing } \\
(\mathbf{2 0} \times \mathbf{5} \mathbf{~ c m})\end{array}$ & $\begin{array}{c}\text { Spacing } \\
(\mathbf{2 0} \times \mathbf{8} \mathbf{~ c m})\end{array}$ \\
\hline Sparkler Ponta & $17.64 \mathrm{Aa}$ & $11.38 \mathrm{Aa}$ \\
Saxa & $20.11 \mathrm{Aa}$ & $10.22 \mathrm{Ab}$ \\
\hline
\end{tabular}

Means followed by the same lowercase letter in the columns, or uppercase letter in the rows, are not different by Tukey's test at $5 \%$ probability.

Batista et al. (2013) found similar results for radish crop yield, with the highest total root yield of 11.81 plant $^{-1}$, which was found at 21 days after the incorporation of $15.6 \mathrm{Mg} \mathrm{ha}^{-1}$ of Calotropis procera biomass.

\section{CONCLUSION}

The spacing between plants has no significant effect on the yield of Sparkler Ponta Branca radish cultivar but significantly affected the yield of the cultivar Saxa, where higher yields are recorded when the spacing between plants was of $5 \mathrm{~cm}$.

\section{ACKNOWLEDGMENTS}

The authors thank the National Council for Scientific and Technological Development (CNPq) for its support to the Research Group in Food, Chemistry, Agronomy, and Water Resources (AQARH) of the Institute Federal of Maranhão, Codó Campus (IFMA).

Conflict of interest: The authors declare that there is no conflict of interest.

\section{BIBLIOGRAPHIC REFERENCES}

Aquino, A. B.; Aquino, B. F.; Hernandez, F. F. F.; Holanda, F. J. M.; Freire, J. M.; Crisóstomo, L. A.; Costa, R. I.; Uchôa, S. C. P.; Fernandes, V. L. B. (1993). Recomendações de Adubação e Calagem para o Estado do Ceará. Fortaleza: UFC. 248p.

Batista, M. A.V.; Bezerra Neto, F; Ambrosio, M. M. Q.; Guimarães, L. M. S.; Saraiva, J. P. B.; Silva, M. L. (2013). Atributos microbiológicos do solo e produtividade de rabanete influenciados pelo uso de espécies espontâneas. Horticultura Brasileira. 31: 587-594.

Bonela, G. D.; Santos, W. P.; Alves Sobrinho, E. A.; Gomes, E. J. C. (2017). Produtividade e qualidade de raízes de rabanete cultivadas sob diferentes fontes residuais de matéria orgânica. Revista Brasileira de Agropecuária Sustentável (RBAS). 07: 66-74.

Cardoso, A. I. I.; Hiraki, H. (2001). Avaliação de doses e épocas de aplicação de nitrato de cálcio em cobertura na cultura do rabanete. Horticultura Brasileira. 19: 328-331.

Caron, B. O.; Pommer, S. F.; Schmidt, D.; Manfron, P. A.; Medeiros, S. L. P. (2004). Crescimento da alface em diferentes substratos. Revista de Ciências Agroveterinárias. 3: 97-104.

Castro Júnior, W. L.; Oliveira, R. A.; Silveira, S. F. R.; Andrade Junior, A. S. (2015). Viabilidade econômica de tecnologias de manejo da irrigação na produção do feijão-caupi, na região dos cocais-MA. Engenharia Agrícola. 35: 406-418. doi: https://doi.org/10.1590/1809-4430-Eng. Agric.v35n3p406-418/2015

Caetano, A. de 0.; Diniz, R. L. C.; Benett, C. G. S.; Salomão, L. C. (2015). Efeito de fontes e doses de nitrogênio na cultura do rabanete. Revista de Agricultura Neotropical. 2: 55-59. 
Cecílio Filho, A. B.; Faquin, V.; Furtini Neto, A. E.; Souza, R. J. (1998). Deficiência nutricional e seu efeito na produção de rabanete. Revista Científica. 26: 231-241.

Cecílio Filho, A. B.; May, A. (2002). Produtividade das culturas de alface e rabanete em função da época de estabelecimento do consórcio. Horticultura Brasileira. 20:501-504.

Cunha, F. F.; Castro, M. A.; Godoy, A. R.; Magalhães, F. F.; Leal, A. J. F. (2017). Irrigação de cultivares de rabanete em diferentes épocas de cultivo no Nordeste Sul-Mato-Grossense. Irriga. 22: 530-546.

Costa, C. C.; Oliveira, C. D.; Silva, C. J.; Timossi, P. C.; Leite, I. C. (2006). Crescimento, produtividade e qualidade de raízes de rabanete cultivadas sob diferentes fontes e doses de adubos orgânicos. Horticultura Brasileira. 24: 118- 122.

Cortez, J. W. M.; Cecílio Filho, A. B.; Coutinho, E. L.; Alves, A. (2010). Cattle manure and N-urea in radish crop (Raphanus sativus). Ciencia e Investigación Agraria. 37: 45-53.

El-Desuki, M.; Salman, S. R.; El-Nemr, M. A.; Abdel-Mawgoud, A. M. R. (2005). Effect of Plant Density and Nitrogen Application on the Growth, Yield and Quality of Radish (Raphanus sativus L.). Journal of Agronomy. 4: 225-229.

Filgueira, F. A. R. (2003). Novo manual de olericultura: agrotecnologia moderna na produção de hortaliças. 2 ed. Viçosa: UFV, 412 p.

Guimarães, M. A; Feitosa, F. C. (2014). Rabanete: condições ideais para o cultivo. Campo \& Negócios. 8:06-09.

Ito, H.; Horie, H. A. A. (2008). Chromatographic method for separating and identifying intact 4-methylthio-3-butenyl glucosinolate in Japanese radish (Raphanus sativus L.). Japan Agricultural Research Quarterly. 42: 109-114. doi: https://doi.org/10.6090/jarq.42.109

Köppen; Geiger. (1928). Distribuição dos tipos de clima na classificação. Recovered from https:// pt.climate-data.org/america-do-sul/brasil/ maranhao/codo-4445/
Linhares, P. C. F.; Pereira, M. F. S.; Oliveira, B. S.; Henriques, G. P. S. A.; Maracajá, P. B. (2010). Produtividade de rabanete em sistema orgânico de produção. Revista Verde de Agroecologia $e$ Desenvolvimento Sustentável. 5: 94-101.

Melo, M. F. (2017). Híbrido de rabanete - Mais lucro no negócio. Campo \& Negócios. 1: 1-4.

Minami, K.; Cardoso, A. I. I.; Costa, F.; Duarte, R. (1998). Efeito do espaçamento sobre a produção em rabanete. Bragantia. 57: 169-173.

Montezano, E. M.; Peil, R. M. N. (2006). Sistemas de consórcio na produção de hortaliças. Revista Brasileira Agrociência. 12: 129-132.

Oliveira, F. L.; Ribas, R. G. T.; Junqueira, R. M.; Padovan, M. P.; Guerra, O.F.R.A. (2010). Interação entre salinidade e fósforo na cultura do rabanete. Revista Ciência Agronômica. 41: 519-526.

Puliti, J. P. M.; Reis, H. B.; Paulino, H. D. M.; Ribeiro, T. C. M.; Teixeira, M. Z.; Chaves, A. S.; Ribeiro, B. R.; Macieira, G. A. A.; Yuri, J. E. (2009). Comportamento da cultura do rabanete em função de fontes e doses de cálcio. Horticultura Brasileira. 27: 3003-3008.

Rezende, B. L.; Cecílio-Filho, A. B.; Feltrim, A. L.; Costa, C. C.; Barbosa, J. C. (2006). Viabilidade da consorciação de pimentão com repolho, rúcula, alface e rabanete. Horticultura Brasileira. 24:3641.

Rodrigues, R. R.; Pizetta, S. C.; Teixeira, A. G.; Reis, E. F.; Hott, M. O. (2013). Produção de rabanete em diferentes disponibilidades de água no solo. Enciclopédia Biosfera. 9: 2121-2130.

Salgado, A. S.; Guerra, J. G. M.; Almeida, D. L.; Ribeiro, R. L. D.; Espindola, J. A. A.; Salgado, J. A. A. (2006). Consórcios alface-cenoura e alface-rabanete sob manejo orgânico. Pesquisa Agropecuária Brasileira. 41: 1141-1147.

Severino, L. S.; Ferreira, G. B.; Moraes, C. R. A.; Gondim, T. M. S.; Cardoso, G. D.; Viriato, J. R.; Beltrão, N. E. M. (2006). Produtividade e crescimento da mamoneira em resposta à adubação orgânica e mineral. Pesquisa Agropecuária Brasileira. 41:879-882. 
Silva, F. A. S.; Azevedo, C. A. V. (2016). The Assistat Software Version 7.7 and its use in the analysis of experimental data. African Journal of Agricultural Research. 11: 3733-3740.

Santos, H. G.; Jacomine, P. K. T.; Anjos, L. H. C.; Oliveira, V. A.; Lumbreras, J. F.; Coelho, M. R.; Almeida, J. A.; de Araujo Filho, J. C.; de Oliveira, J. B.; de.; Cunha, T. J. F. (2018). Sistema Brasileiro de Classificação de Solos. 5. ed. Brasília, DF: Embrapa. 355p.

Vitti, M.; Vidal, M.; Morselli, T. B. G. A.; Faria, J. L. C. (2007). Resposta do rabanete a adubação orgânica em ambiente protegido. Horticultura Brasileira. 2:1158-1161. 